\title{
Utilization of Rhizobacteria and Spent Mushroom Compost for the Management of
} Bacterial Wilt of Potato

\author{
Adeela Altaf*, Muhammad Inam ul Haq \\ Department of Plant Pathology, PMAS Arid Agriculture University, Rawalpindi, Pakistan.
}

ART ICLE I N F O

\section{Article History}

Received: June 11, 2020

Revised: August 21, 2020

Accepted: October 03, 2020

\section{Keywords}

Biological control

Bacterial wilt disease

Rhizobacteria

Spent mushroom compost

Potato

\begin{abstract}
A B S T RA C T
Potato (Solanum tuberosum L.) is the fourth most important staple food in the world after wheat (Triticum aestivum L.), rice (Oryza sativa L.) and maize (Zea mays L.). In Pakistan, potato crop is cultivated over an area of 191.6 million hectares. On an average potato production in Pakistan is 20 tonnes per hectare. A target has set by The Government of Pakistan to produce about 4.871 million tons potatoes during Rabi Season 2020-21. (Federal Committee on Agriculture FCA) The potato production exceeds 376 million tonnes harvested from an area of 19.25 million hectares in the world (FAOSTAT 2018). Ralstonia solanacearum causing bacterial wilt is a major threat to potato production. Management through biocontrol agents is one of the best methods that can replace synthetic chemical-based formulations. In the current study combine effect of antagonist rhizobacteria as biocontrol agent and spent mushroom compost as biofertilizer were tested against bacterial wilt disease pathogen. Potato plant samples infected with $R$. solanacearum and rhizobacteria were collected from potato growing fields in Rawalpindi. Out of twenty tested antagonistic rhizobacterial isolates, only three viz., Rh10, Rh12 and $\mathrm{Rh} 15$ showed maximum inhibitory effect against $R$. solanacearum. In another experiment different combinations of treatments containing rhizobacteria alone or combined with fresh and spent mushroom composts were also tested against the bacterial wilt pathogen under laboratory conditions. Combination of rhizobacteria along with weathered compost (T5) reduced the disease incidence to $15.92 \%$ when compared against $77.81 \%$ in control after six weeks. Significant increase in plant height up to $41.83 \mathrm{~cm}$ was also observed as compared to control viz., $35.5 \mathrm{~cm}$. Similarly, T2 (only fresh compost), T3 (containing fresh compost along with rhizobacteria) and T4 (rhizobacteria along with weathered compost) also showed better results as compared to against control (T0) where there was no application of rhizobacteria and compost. Application of rhizobacterial along with spent mushroom compost can significantly reduce the disease incidence along with the improvement in plant growth parameters.
\end{abstract}

Corresponding Author: Adeela Altaf

Email: adeelaaltaf15@gmail.com

(c) The Author(s) 2020.

\section{INTRODUCTION}

Potato is (Solanum tuberosum L.) popularly known as "The king of vegetables. Potato is the most important tuber crop and has major economic importance in the world. It is the fourth most important staple food, ranking first in volume produced among root and tuber crops worldwide. It is generally a high yielding crop, but the crop is vulnerable to the attack of a number of diseases that are caused by fungi, bacteria, viruses and nematodes. In Pakistan, potato crop is cultivated over an 
area of 180 thousand hectares. On an average potato production in Pakistan is 20 tons per hectare. The potato production exceeds 376 million tons harvested from an area of 19.25 million hectares in the world (FAOSTAT 2018).

Bacterial wilt caused by Ralstonia solanacearum is a major disease affecting potato production worldwide and is mainly categorized as both seed-borne and soil-borne disease. It is highly challenging and one of the most destructive diseases of solanaceous crops worldwide (Hayward, 2005). It causes enormous losses to many economically important crops, such as tomato, potato, eggplant, pepper, tobacco, banana, chili, and peanut (Liu et al., 2005). R. solanacearum causes wilt in over 450 host species in 54 botanical families (Allen et al., 2005). More than $90 \%$ yield losses caused by bacterial wilt in tomato, potato, and other host crops if kept uncontrolled. (Aslam et al., 2017).

Management of plant diseases has become a challenge for the plant pathologist for sustainable agriculture. Various control strategies including soil fumigation (French and Sequeira, 1994), planting of resistant cultivars, transgenic resistant plants, crop rotation, soil amendments, integrated control and biological control have been developed. The application of pesticides caused huge losses and health hazard problems. Out of different organisms used as biocontrol agents, rhizosphere microorganisms provide a front-line defense against pathogen attack and are ideal for use as biocontrol agents (Siddiqui, 2006). Mushroom production is currently the biggest solid-state-fermentation industry in the world (Soccol and Vandenberghe, 2003). Spent mushroom compost (SMC) is produced by the mushroom industry as a residual byproduct. It is a good source of nutrients and acts as a beneficial soil conditioner (Aslam and Saifullah, 2013). Application of spent mushroom compost as a soil amendment reduces early dying of potato caused by Verticillium dahliae (Haghighi et al., 2006).

Some edible mushrooms such as Lentinus edodes, Boletus edulis, Pleurotus ostreatus and Agaricus bisporus have been reported to have antimicrobial properties. (Susana et al., 2009). Aslam and Saifullah, 2013 have reported that SMC has some phenolic compounds with antimicrobial activity, which exist as an effective biocontrol of root knot nematode (Meloidogyne spp.) on tomato. The present study was planned to explore the biocontrol ability of selected rhizobacterial isolates along with spent mushroom compost against $R$. solanacearum.

\section{METHODS AND MATERIAL}

\section{Survey and sample collection}

A comprehensive survey was conducted in different potato growing areas of Rawalpindi district, Pakistan for the collection of plant samples with characteristic symptoms of bacterial wilt. Soil samples from the rhizosphere area of healthy potato plants were also collected for the isolation of beneficial rhizobacteria. All the samples were collected in polythene bags and labelled properly. Samples were brought to the laboratory and were kept at $-4{ }^{\circ} \mathrm{C}$ in a refrigerator till further use in experimentation.

\section{Isolation and identification of pathogen}

Stem sections with characteristic symptoms of bacterial wilt were cut into small pieces and were rinsed with distilled water to make them free from soil debris and other contaminants. Stems sections were surface sterilized by treating with $1 \%$ Chlorox and were dipped in test tube containing distilled water followed by shaking on vortex for few seconds. This will assist the bacteria to ooze out from the infected samples. Loop full of bacterial suspension was streaked on petri plates containing Nutrient agar (NA) and 2, 3, 5 - triphenyltetrazolium chloride media (TTC) followed by incubation at $30^{\circ} \mathrm{C}$ for 48 hours. Reddish bacterial colonies were appeared after two days. Purification was carried out by picking single bacterial colony and streaking on TTC medium containing petri plates (Begum et al., 2012).

\section{Pathogenicity confirmation for $R$. solanacearum}

Pathogenicity of the $R$. solanacearum was tested on healthy young seedlings of potato plants. Seeds of susceptible potato variety were sown in sterilized soil. Young seedlings of potato plants were incubated with 20 $\mu \mathrm{l}$ (e.g., a drop) of a bacterial suspension of $R$. solanacearum at $10-8$ cells $/ \mathrm{ml}$ with a $1 \mathrm{ml}$-propylene syringe. Plants in the control treatment were treated with distilled water only and three replications for each isolate were maintained. Plants were monitored for up 3 weeks for symptoms expression and re-isolation of pathogenic bacteria was carried out from wilted plants by streaking the bacterial suspensions on TTC medium.

\section{Isolation of plant growth promoting rhizobacteria}

Plant Growth Promoting Rhizobacteria (PGPR) were isolated from the soil and healthy root samples by serial dilution method. Roots of healthy tomato plants were 
washed gently with distilled water to remove the adhered soil debris. $1 \mathrm{~g}$ root sections were added in a flask containing $200 \mathrm{ml}$ sterile water and were shaken on rotary shaker at $150 \mathrm{rpm}$ for half an hour. Serial dilutions were streaked on nutrient agar medium containing plates and incubated at $28^{\circ} \mathrm{C}$ for $48 \mathrm{~h}$. Purification was done by re-streaking the single bacterial colonies on nutrient agar media. Pure cultures of PGPR strains were identified using morphological and physiological characteristics (Akhtar et al., 2009).

\section{Biochemical tests for confirmation of $\boldsymbol{R}$. solanacearum and antagonistic rhizobacteria}

Different biochemical tests viz., Gram staining, KOH tests, catalase oxidase test, and Kovac oxidase tests were performed for the confirmation of $R$. solanacearum and antagonistic rhizobacteria.

\section{Gram Staining}

Bacterial smear was prepared on glass slides and a drop of $0.5 \%$ crystal violet was added to it followed by rinsing with tape water for 60 seconds. One drop of iodine solution was added to it and rinsed again with tap water. For decolonization, the glass slides were treated with $95 \%$ ethanol for about 30 seconds. After washing the specimen was counter stained with safranin for about 10 seconds. Glass slide was dried for few seconds and examined under microscope at different magnification power (10X, 40X and 100X) as described by (Begum et al., 2012).

\section{Potassium hydroxide loop test}

In this test, 48 hours pure culture of $R$. solanacearum was picked up by sterilized toothpick and mixed with fresh $3 \%$ potassium hydroxide solution on glass slide for 10 seconds. On continuous stirring for few seconds, loop formation was noticed for the confirmation of gram positive or gram-negative bacteria (Chaudhry and Rashid, 2011).

\section{Catalase oxidase test}

Pure single colony of bacteria was mixed with single drop of $3 \%$ of hydrogen peroxide $\left(\mathrm{H}_{2} \mathrm{O}_{2}\right)$ with the help of an inoculating needle. Few seconds later gas bubbles were formed and observed with the naked eye (Reynolds, 2004).

\section{Kovacs Oxidase Test}

Small amount of the bacteria was spread on the filter paper impregnated with $1 \%$ oxidase reagent solution and rubbed it with the help of sterilized toothpick for few seconds. Development of deep blue/ purple color is noticed for bacterial confirmation in 10-60 seconds. (Hossain et al., 2007)

\section{In-vitro evaluation of pgpr for their antagonistic activity against $R$. solanacearum}

Selected strains of rhizobacteria were tested for their antagonistic activities against $R$. solanacearum by zone inhibition method. 48 hours old culture of rhizobacterial strains were placed in center of the petri plates and $R$. solanacearum discs in the surrounding. Petri plates were incubated for two days. Efficacy of tested rhizobacterial isolates was recorded by measuring the inhibition zone against the control treatment where there was no application of rhizobacteria.

\section{Collection of spent mushroom compost}

Spent Mushroom Compost (SMC) with two degrees of decaying: fresh and six months old were taken from the National Agriculture Research Center (NARC). Islamabad, Pakistan.

\section{In-vitro evaluation of rhizobacteria and spent mushroom compost}

Different treatments of SMC were made and subjected to check their efficacy against pathogenic $R$. solanacearum. Soil mixture alone or in combination with fresh and weathered compost was filled into the pots. Suspension of $R$. solanacearum was prepared and poured into pots. Potato tubers were treated with 48 hours old culture of antagonistic rhizobacteria for 1 hour and were sown into pots containing amended soil. Three replications for each treatment were maintained and control treatment contains only the application of pathogenic $R$. solanacearum. Data on diseases incidence was taken on weekly basis by using the formula given below:

$$
\text { Disease incidence }(\%)=\frac{\text { Number of infected plants }}{\text { Total number of plants }} \times 100
$$

Growth parameters viz., Plant height (P.H), shoot length $(\mathrm{SL})$, root length (RL), fresh root weight (FRW), fresh shoot weight (FSW), dry root weight (DRW), dry shoot weight (DSW) was recorded. The data of all the treatments was compared with the control treatment. Collected data was analyzed statistically by using Complete Randomized Design (CRD) with three replications for each treatment. 


\section{RESULTS}

Isolation identification and pathogenicity of $\boldsymbol{R}$. solanacearum

After isolation and identification of $R$. solanacearum, pathogenicity test was performed to check the virulence of the pathogen. Out of twenty-five different tested isolates, only three isolates showed positive results to be pathogenic as given in Table 1 .

Table 1. Pathogenicity confirmation of $R$. solanacearum.

\begin{tabular}{ccc}
\hline R. solanacearum & & \\
\hline RS-4 & RS-10 & RS-15 \\
\hline+ & + & + \\
+ & + & + \\
+ & + & + \\
\hline
\end{tabular}

Biochemical tests for confirmation of $\boldsymbol{R}$. solanacearum and antagonistic rhizobacteria

Different biochemical tests were performed for the confirmation of $R$. solanacearum and antagonistic rhizobacteria and the results are given in Table 2. Gram staining test showed positive results for all the bacterial gents except $\mathrm{Rh}-10$ and $\mathrm{Rh}-15$ while $\mathrm{KOH}$ test results were negative for Rh-10 and Rh-12. Catalase oxidase test results were positive for all the tested bacterial isolates. Kovacs oxidase test was positive for all the tested bacterial strains except Rh-15. All the bacterial agents were observed rod shaped under microscope.

Table 2. Biochemical tests for the identification of $R$. solanacearum and PGPR isolates.

\begin{tabular}{|c|c|c|c|c|c|c|c|}
\hline \multirow[t]{2}{*}{ Biochemical Test } & \multicolumn{2}{|c|}{ R. solanacearum } & \multicolumn{4}{|c|}{ Antagonistic Bacteria } & \multirow{2}{*}{ Cell Morphology } \\
\hline & RS-4 & RS-10 & RS-15 & Rh-10 & Rh-12 & Rh-15 & \\
\hline Gram stain reaction & + & + & + & - & + & - & Rod shaped \\
\hline $\mathrm{KOH}$ Test' & + & + & + & - & - & + & Rod shaped \\
\hline Catalase Oxidase Test & + & + & + & + & + & + & Rod shaped \\
\hline $\begin{array}{l}\text { Kovacs Oxidase } \\
\text { Test }\end{array}$ & + & + & + & + & + & - & Rod shaped \\
\hline
\end{tabular}

Determination of antagonistic activity of maximum antagonistic potential against the pathogenic rhizobacteria bacteria and were preferred for further study. Among the

Zone inhibition technique was used to test the efficacy of rhizobacterial isolates against $R$. solanacearum. Results of antagonistic potential of all the test rhizobacterial isolates against pathogens were observed and recorded. Data on radial growth of pathogen isolates was measured at the end of second, fourth and sixth days of incubation period. Out of 20 tested isolates Rh-10, Rh-12, and Rh-15 showed three selected isolates $\mathrm{Rh}-12(15 \mathrm{~mm})$ results in maximum inhibition as compared to the Rh-10 (11 mm) and Rh-15 (9 $\mathrm{mm}$ ). The growth inhibition of the pathogen is attributed the antibiotic, antibacterial compounds and siderophore production by the rhizobacterial isolates. Data regarding zone of inhibition is given Table. 3. Most efficient rhizobacterial isolates were selected for further tests.

Table 3. Growth Inhibition of $R$. solanacearum by rhizobacterial isolates ( $\mathrm{mm})$.

\begin{tabular}{ccc}
\hline Sr No. & Isolates & Zone of Inhibition (mm) \\
\hline 1 & Rhz 1 & 3.00 \\
2 & Rhz 2 & 0.00 \\
3 & Rhz 3 & 1.00 \\
4 & Rhz 4 & 2.00 \\
5 & Rhz 5 & 6.5 \\
6 & Rhz 6 & 0.00 \\
7 & Rhz 7 & 1.00 \\
8 & Rhz 8 & 4.5 \\
9 & Rhz 9 & 6.00 \\
\hline
\end{tabular}




\begin{tabular}{lcc}
\hline 10 & Rhz 10 & 11 \\
11 & $\operatorname{Rhz} 11$ & 1.00 \\
12 & $\operatorname{Rhz} 12$ & 15 \\
13 & $\operatorname{Rhz} 13$ & 0.00 \\
14 & $\operatorname{Rhz} 14$ & 1.00 \\
15 & $\operatorname{Rhz} 15$ & 9 \\
16 & $\operatorname{Rhz} 16$ & 4.5 \\
17 & $\operatorname{Rhz} 17$ & 2.00 \\
18 & $\operatorname{Rhz} 18$ & 5.00 \\
19 & $\operatorname{Rhz} 19$ & 9.00 \\
20 & $\operatorname{Rhz} 20$ & 0.00 \\
\hline
\end{tabular}

In-vitro evaluation of rhizobacteria and spent mushroom compost against $R$. solanacearum

In vitro evaluation of rhizobacterial isolates along with fresh and weathered compost was carried out. Disease incidence in different treatments was monitored after each week and compared the results with the control as shown in the Table 4 and 5. Results showed that among all the tested combinations of rhizobacteria and SMC, $R$. solanacearum + soil + Weathered (Six-month old compost) + Rhizobacteria showed maximum reduction in disease incidence when compared against the control treatment where there was the application of pathogenic $R$. solanacearum followed by T4 ( $R$. solanacearum + soil + Weathered (Six-month old compost)) and T3 (R. solanacearum + soil + Fresh compost + Rhizobacteria $)$. Among all the treatments, T1 (R. solanacearum (RS) + soil + Rhizobacteria) showed the minimum effectiveness in disease control.

Table 4. In-vitro evaluation of rhizobacteria and spent mushroom compost against $R$. solanacearum.

\begin{tabular}{ccccccc}
\hline \multirow{2}{*}{ Treatments } & \multicolumn{7}{l}{ Disease Incidence $\%\left(1^{\text {st }}\right.$ Year $)$} \\
\cline { 2 - 6 } & 7DAYS & 14DAYS & 21DAYS & 28DAYS & 35DAYS & 42DAYS \\
\hline C & 29.42 & 45.78 & 54.57 & 58.13 & 63.07 & 76.81 \\
T1 & 0 & 16.99 & 20.55 & 23.6 & 26.06 & 27.71 \\
T2 & 0 & 15.563 & 17.37 & 19.06 & 22.26 & 23.98 \\
T3 & 0 & 14.26 & 16.05 & 18.74 & 21.54 & 22 \\
T4 & 0 & 12.5 & 13.85 & 16.45 & 17.56 & 18.25 \\
T5 & 0 & 11.396 & 12.99 & 13.86 & 14.97 & 15.92 \\
\hline
\end{tabular}

C = Control, $\mathbf{T 1}=R$. solanacearum $(\mathrm{RS})+$ soil + Rhizobacteria, $\mathbf{T} 2=R$. solanacearum + soil + Fresh compost $(\mathrm{FC}), \mathbf{T} 3=R$. solanacearum + soil + Fresh compost + Rhizobacteria, $\mathbf{T} 4=R$. solanacearum + soil + Weathered (Six-month old compost), $\mathbf{T} 5=R$. solanacearum + soil + Weathered (Six-month old compost $)+$ Rhizobacteria.

Table 5. In-vitro evaluation of rhizobacteria and spent mushroom compost against $R$. solanacearum.

\begin{tabular}{ccrrrrc}
\hline \multirow{2}{*}{ Treatments } & \multicolumn{7}{l}{ Disease Incidence $\%$ (2n Year) } \\
\cline { 2 - 7 } & 7DAYS & 14DAYS & 21DAYS & 28DAYS & 35DAYS & \multicolumn{1}{c}{ 42DAYS } \\
\hline C & 28.85 & 42.35 & 54.44 & 62.46 & 66.42 & 77.47 \\
T1 & 0 & 17.06 & 20.6 & 25.21 & 26.73 & 31.71 \\
T2 & 0 & 15.97 & 17.71 & 22.42 & 23.09 & 24.65 \\
T3 & 0 & 14.63 & 16.1 & 19.24 & 21.54 & 22.6 \\
T4 & 0 & 12.78 & 14.2 & 15.71 & 16.92 & 18.61 \\
T5 & 0 & 11.61 & 12.99 & 14.05 & 15.03 & 15.94 \\
\hline
\end{tabular}

C = Control, $\mathbf{T 1}=R$. solanacearum (RS) + soil + Rhizobacteria, $\mathbf{T} 2=R$. solanacearum + soil + Fresh compost (FC), $\mathbf{T} 3=R$. solanacearum + soil + Fresh compost + Rhizobacteria, $\mathbf{T} 4=R$. solanacearum + soil + Weathered (Six-month old compost), $\mathbf{T} \mathbf{5}=R$. solanacearum + soil + Weathered (Six-month old compost) + Rhizobacteria. 


\section{Data on growth parameters}

Different growth parameters viz., Plant height, fresh and dry root and shoot weight were recorded. The data of all the treatments were compared with the control is given in Table 6 and 7. In response to the application of various treatments, all the treatments showed an increase in the plant height when compared to against control treatment where there was only pathogenic bacterial suspension was applied. All the treatments showed almost same results in enhancing the plant growth parameters viz., Fresh Root Weight, Fresh Shoot Weight, Dry Root Weight and Dry Shoot Weight. Among all the treatments, T5 (R. solanacearum + soil + Weathered (Six-month old compost) + Rhizobacteria) results in maximum reduction in disease severity when compared against control treatment.

Table 6. Growth parameters in response to the applications of PGPR and SMC.

\begin{tabular}{ccccccc}
\hline \multirow{2}{*}{ Treatments } & \multicolumn{7}{c}{ Growth Parameters (1 ${ }^{\text {st }}$ year) } \\
\cline { 2 - 7 } & P.H & FRW & FSW & DRW & DSW & DS \\
\hline C & 35.5 & 11.83 & 23.66 & 8.14 & 15.17 & 74.49 \\
T1 & 38.5 & 14.91 & 23.58 & 5.57 & 17.86 & 36.25 \\
T2 & 40.5 & 17.33 & 23.16 & 8.72 & 18.11 & 25.83 \\
T3 & 41.33 & 17.16 & 24.16 & 8.94 & 17.31 & 23.16 \\
T4 & 40.5 & 17.36 & 23.14 & 8.51 & 18.36 & 26.33 \\
T5 & 41.83 & 15.66 & 26.16 & 8.51 & 19.61 & 25.45 \\
\hline
\end{tabular}

P.H = Plant Height, FRW= Fresh Root Weight, FSW = Fresh Shoot Weight, DRW = Dry Root Weight, DSW = Dry Shoot Weight, $\mathbf{D S}=$ Disease Severity .

Table 7. Growth parameters in response to the applications of PGPR and SMC.

\begin{tabular}{ccccccc}
\hline \multirow{2}{*}{ Treatments } & \multicolumn{7}{c}{ Growth Parameters (2 ${ }^{\text {nd }}$ year) } \\
\cline { 2 - 7 } & P.H & FRW & FSW & DRW & DSW & DS \\
\hline C & 35.5 & 11.83 & 23.66 & 8.14 & 14.75 & 74.49 \\
T1 & 38.5 & 14.91 & 23.58 & 5.57 & 17.86 & 36.25 \\
T2 & 40.5 & 17.33 & 23.16 & 8.72 & 18.11 & 25.83 \\
T3 & 41.33 & 17.16 & 24.16 & 8.94 & 17.31 & 23.16 \\
T4 & 40.5 & 17.36 & 23.14 & 8.51 & 18.36 & 26.33 \\
T5 & 41.83 & 15.66 & 26.16 & 8.51 & 19.61 & 25.45 \\
\hline
\end{tabular}

P.H = Plant Height, FRW= Fresh Root Weight, FSW = Fresh Shoot Weight, DRW = Dry Root Weight, DSW = Dry Shoot Weight, $\mathbf{D S}=$ Disease Severity.

\section{DISCUSSION}

Management of plant diseases has become a challenge for the plant pathologists for sustainable agriculture. The application of pesticides damaged the crops and caused health hazard problems. Increasing awareness and health issues associated with the applications of pesticides, an alternative method has been adopted by plant protection to reduce that risk. Biocontrol is one of the best strategies used by plant pathologists for disease management. Among various organisms which serve as a biocontrol agent, rhizosphere microorganisms (PGPR) which supply a front-line protection against pathogenic attack and are ideal for use (Siddiqui, 2006). PGPR, which not only exerts a beneficial effect on the plant they colonize but also interacts with the plant roots as well as with other microorganisms in the rhizosphere. Some of the PGPR are antagonists to recognized root pathogens and result in prevention of disease development. Introduction of biocontrol agents from outside in the rhizosphere to achieve disease suppression was also described by Maji and Chakrabartty (2014).

Many studies have shown that the biological control of bacterial wilt can be done by using various BMs (biological microorganisms) including Bacillus (Wei et al., 2011), Pseudomonas spp. (Ramesh et al., 2009), Streptomyces spp. (Boukaew et al., 2011), Acinetobacter spp. and Enterobacter spp. (Xue et al., 2009), Stenotrophomonas maltophilia (Messiha et al., 2007) and Actinomycetes spp. (Tan et al., 2006). Sarkar and 
Chaudhuri 2013 have reported the suppressive effect of some antagonistic bacteria on $R$. solanacearum. Some naturally occurring antagonistic rhizobacteria such as Bacillus spp., Pseudomonas spp. have been reported to control this disease. B. subtillus have been reported to be the best application in controlling bacterial wilt of tomato in both in-vitro and in greenhouse conditions.

Lian et al., 2011 reported that rhizobacteria are the most effective over other antagonistic. In the greenhouse experiment inhibition had been observed when the antagonistic was applied before or simultaneously with the pathogen, while antagonistic was less effective when applied after pathogen inoculation. This indicated that the biocontrol effects of the antagonistic rhizobacterial strains are more likely to be a preventive effect rather than a therapeutic effect on the disease. Spent mushroom compost (SMC) is produced by the mushroom industry as a residual byproduct. It is a good source of nutrients and acts as a beneficial soil conditioner. The occurrence of phenolic compounds in SMC has antimicrobial activity on tomato (Aslam et al., 2013). Application of spent mushroom compost (SMC) as a soil amendment reduces early dying of potato caused by Verticillium dahliae (Haghighi et al., 2006).

Keeping in view the environmental issues and importance of biological control, the present study was planned to explore the biocontrol of $R$. solanacearum by using rhizobacteria and spent mushroom compost. Recent studies have proved that biological control of bacterial wilt disease could be achieved by using spent mushroom compost and antagonistic rhizobacteria. Different biochemical tests i-e Gram staining, $\mathrm{KOH}$ tests, catalase oxidase test, Kovac oxidase test were used for the confirmation of $R$. solanacearum and antagonistic rhizobacteria in this study were similar to the result reported by Begum et al., 2012 and Kuarabachew et al., 2007. In the in vitro antibiosis, the inhibition zone of Rh10, Rh-12 and Rh15 showed 11, 15 and 9mm, respectively. Similarly, in the in vitro antibiosis, the smallest and largest inhibition zone of 1.2 and $2.4 \mathrm{~cm}$ diameter were caused by Pfri (Indian isolates) and Pfw1 (Wolayta isolates) respectively. Pfw1 have 200\% efficiency being the most efficient isolates followed by Pfs2 and Pfwt3 with $125 \%$ and $111 \%$ efficiency, respectively (Kuarabachew et al., 2007).

Spent mushroom composts fresh and weathered showed lesser severity than PGPR. These results indicate that the two kinds of composts had suppressive characteristics to bacterial wilt with respect to the reference growth media. No significant difference in the reduction of bacterial wilt incidence in potato was observed in the first week. Furthermore, two consecutive years of pot experiments showed that bacterial wilt incidence was lower down in the treatment T5 (weathered + PGPR) i.e 11.39\%, $12.99 \%, 13.86 \%, 14.97 \%$ and $14.97 \%$ respectively (Singh et al., 2012).

This work demonstrates that the activity in the compost mixed with PGPR was biological in nature. Beneficial rhizobacteria, as well as SMC, can induce systemic resistance in plants (Zhang et al., 1998). The microflora in the compost along with PGPR that induced SAR remains unknown. These results suggest, however, that significant opportunities exist for the development of improved inoculants for composts yielding novel disease control strategies. Compost along with PGPR also enhances plant growth parameters i.e Plant height, FRW, FSW, DRW and DSW. T5 $(\mathrm{T} 5=R$. solanacearum + soil + Weathered (Sixmonth old compost) + Rhizobacteria] showed better growth as compared to control (C). In the same way, bacterization of tuber with selected efficient of an antagonistic rhizobacteria along with weathered compost T5 significantly increased the plant height, fresh and dry weight of root and shoot, disease severity by $41.83 \%$, $15.66 \%, 26.16 \%, 8.51 \%, 19.61 \%, 25.45 \%$ respectively as compared to T0 (control).

This result agreed with Kuarabachew 2007 where they found an increased plant height and dry weight by $76.89 \%$ and $28.44 \%$, respectively as compared to T1. Potato tuber planted after bacterization in treatments $\mathrm{T} 3, \mathrm{~T} 4$ and T5 $[\mathrm{T} 3=R$. solanacearum + soil + Fresh compost + Rhizobacteria, $\mathrm{T} 4=R$. solanacearum + soil + Weathered (Six-month old compost), T5 $=R$. solanacearum + soil + Weathered (Six-month old compost) + Rhizobacteria] showed the most significant growth enhancement (Plant height and dry weight) when compared to potato plants in other treatments C-T1 [C = Control, $\mathrm{T} 1=R$. solanacearum (RS) + soil + Rhizobacteria]. This could be explained on the basis of the possibility of production of growth stimulating substance (hormone), increased nutrient availability in presence of isolates. The results presented in this study suggest that the antagonistic rhizobacteria isolated from the soils, when mixed with fresh and weathered compost according to Kuarabachew 2007.

\section{CONCLUSIONS}

It was concluded that the application of rhizobacterial 
along with spent mushroom compost can reduce the disease incidence along with the improvement in the plant growth parameters without a significant reduction in plant growth.

\section{CONFLICT OF INTEREST}

The authors declare that they have no conflicts of interest.

\section{AUTHORS CONTRIBUTIONS}

All the authors contributed equally to this work.

\section{REFERENCES}

Akhtar, M.J., H.N. Asghar, K. Shahzad and M. Arshad. 2009. Role of plant growth promoting rhizobacteria applied in combination with compost and mineral fertilizers to improve growth and yield of wheat (Triticum aestivum L.). Pakistan Journal of Botany, 41(1): 381-390.

Allen, C., P. Prior and A.C. Hayward. 2005. Bacterial Wilt Disease and the Ralstonia solanacearum Species Complex. APS Press, St. Paul, MN, USA, 528.

Aslam, S., and J. Saifullah. 2013. Organic management of root knot nematodes in tomato with spent mushroom compost. Department of plant pathology, The University of Agriculture, Peshawar - Pakistan. Sarhad Journal of Agriculture, 29(1): 63-69.

Aslam, M.N., T. Mukhtar, M.A. Hussain and M. Raheel. 2017. Assessment of resistance to bacterial wilt incited by Ralstonia solanacearum in tomato germplasm. Journal of Plant Diseases and Protection, 124(6): 585-590.

Begum, N., M.I. Haque, T. Mukhtar, S.M. Naqvi and J.F. Wang. 2012. Status of Bacterial Wilt caused by Ralstonia solanacearum in Pakistan. Pakistan Journal of Phytopathology, 24(1): 11-20.

Boukaew, S., S. Chuenchit and V. Petcharat. 2011. Evaluation of Streptomyces spp. for biological control of Sclerotium root and stem rot and Ralstonia wilt of chili pepper," BioControl, 56(3): 365-374.

Chaudhry Z, Rashid H. 2011. Isolation and characterization of Ralstonia solanacearum from infected tomato plants of Soan Skesar valley of Punjab. Pakistan Journal of Botany, 43(6):29792985.

FAOSTAT. 2018. Food and agriculture Organization of the United Nations, Rome, Italy. Accessed 13 March
2018.

French, E. and L. Sequeira. 1994. Strains of Pseudomonas solanacearum from Central and South America: a comparative study. Phytopathology, 60: 506-512.

Haghighi M, K. Mohsen and T. Ali. 2006. Effect of Decay Level of SMC (Spent Mushroom Compost) and Media Diameters and Compound on Turfculture in Hydromulching Method. Iran. International Journal of Agriculture and Biology, 8(5): 691- 693.

Hayward. A.C. 2005. Research on BW: A perspective on International links and access to literature. In: Bacterial wilt Disease and the $R$. solanacearum species Complex. eds. Allen, C., P. Prior and A. C. Hayward. American Phytopathological Society, 3340 Pilot Knob Road, St. Paul, Minnesota, U. S. A. pp. $1-8$.

Hossain, M.A., M.D. Hossain, K.M. Nasiruddin and M.A.R. Khokon. 2007. Plasmid DNA analysis from Pseudomonas spp. and Ralstonia solanacearum and their reaction to antibiotics. Bangladesh Journal of Crop Science, 18(1): 187-193.

Kuarabachew, H., A. Fasil and H. Yaynu. 2007. Evaluation of Ethiopian Isolates of Pseudomonas fluorescens as biocontrol agent against potato bacterial wilt caused by Ralstonia (Pseudomonas) solanacearum Acta Agriculturae Slovenica, 90(2): 125-135.

Lian, L., Z. Wu, L. Xie, L.S. Benyon and Y. Duan. 2011. Antagonistic activity of Bacillus subtilis SB1 and its biocontrol effect on tomato bacterial wilt. Biocontrol, 41(2): 219-224.

Liu, M., M. Zhang, J. Ji, F. Yin, Y. Zhang, Y. Tu and Y. Ye. 2005. Advances in research on bacterial wilt of ginger in China. Chinese Agricultural Science Bulletin, 21(6):337-340.

Maji, S. and P.K. Chakrabartty. 2014. Biocontrol of bacterial wilt of tomato caused by Ralstonia solanacearum by isolates of plant growth promoting rhizobacteria Australian Journal of Crop Sciences, 8(2): 208-214.

Messiha, N.A.S., A.D. van Diepeningen, N.S. Farag, S.A. Abdallah, J.D. Janse and A.H.C. van Bruggen. 2007. Stenotrophomonas maltophilia: a new potential biocontrol agent of Ralstonia solanacearum, causal agent of potato brown rot. European Journal of Plant Pathology, 118(3): 211-225.

Ramesh, R, Joshi, A. A., Ghanekar, M.P. 2009. Pseudomonas: Major endophytic bacteria to suppress bacterial wilt pathogen Ralstonia solanacearum in the eggplant (Solanum melongena 
L.). World Journal of Microbiology and Biotechnology, 25: 47-55.

Reynolds J., 2004. Lab procedures manual: Biochemical tests. Richland College. http://www.rlc. dcccd.edu/mathsci/Reynolds/micro/lab_manual/ TOC.html.

Sarkar, S. and S. Chaudhuri 2013. Evaluation of the biocontrol potential of Bacillus subtilis, Pseudomonas aeruginosa and Trichoderma viride against bacterial wilt of Tomato. Asian Journal of Biological and Life sciences, 2(2): 146-151.

Siddiqui, Z.A. 2006. PGPR: prospective biocontrol agents of plant pathogens. In: Siddiqui ZA (ed) PGPR: biocontrol and biofertilization. Springer, The Netherlands. 111-142.

Singh, D., D.K. Yadav, S. Sinha and B.K. Upadhyay. 2012. Utilization of plant growth promoting Bacillus subtilis isolates for the management of bacterial wilt incidence in tomato caused by Ralstonia solanacearum race 1 biovar 3 . Indian Phytopathology, 65(1): 18-24.

Soccol, C.R. and L.P.S. Vandenberghe. 2003. Overview of applied solid-state fermentation in Brazil. Biochemical Engineering Journal, 13(2-3): 205218.

Susana, S.A., C.R. Anguina., G. Reglera and C.S. Rivas. 2009.
Improvement of antimicrobial activity of edible mushroom extracts by inhibition of oxidative enzymes. International Journal of Food Science and Technology, 44(5): 1057-1064.

Tan, G.Y.A., A.C. Ward and M. Goodfellow. 2006. Exploration of Amycolatopsis diversity in soil using genus-specific primers and novel selective media. Systematic and Applied Microbiology, 29(7): 557569.

Wei, X., M. Luo, L. Xu, Y. Zhang, X. Lin, P. Kong and H. Liu. 2011. Production of fibrinolytic enzyme from Bacillus amyloliquefaciens by fermentation of chickpeas, with the evaluation of the anticoagulant and antioxidant properties of chickpeas. Journal of Agricultural and Food Chemistry, 59(8): 39573963.

Xue, Q.Y., Y. Chen, S.M. Li, L.F. Chen, G.C. Ding, D.W. Guo and J.H. Gou. 2009. Evaluation of the strains of Actinobacter and Enterobacter as potential biocontrol agents against Ralstonia wilt of tomato. Biological Control, 48(3): 252-258.

Zhang, W., D.Y.Han, W.A. Dick, K.R. Davis and H.A.J. Hoitink. 1998. Compost and compost water extract-induced systemic acquired resistance in cucumber and Arabidopsis. Phytopathology, 88(5): 450-455.

Publisher's note: EScience Press remains neutral with regard to jurisdictional claims in published maps and institutional affiliations.

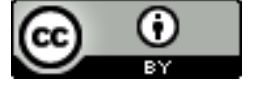

Open Access This article is licensed under a Creative Commons Attribution 4.0 International License, which permits use, sharing, adaptation, distribution and reproduction in any medium or format, as long as you give appropriate credit to the original author(s) and the source, provide a link to the Creative Commons license and indicate if changes were made. The images or other third-party material in this article are included in the article's Creative Commons license, unless indicated otherwise in a credit line to the material. If material is not included in the article's Creative Commons license and your intended use is not permitted by statutory regulation or exceeds the permitted use, you will need to obtain permission directly from the copyright holder. To view a copy of this license, visit http://creativecommons.org/licenses/by/4.0/. 